\title{
French Firm's Financing Choices: Towards a Reconciliation of the Static Trade-Off Theory and the Pecking Order Theory?
}

\author{
Gharsalli Mazen \\ Occidentale Bretagne University \\ CS 93837-29238 BREST cedex 3 \\ France \\ Tel: +33-699-519-115Ｅ-mail: mezen@imel.org \\ Accepted: August 18, 2011 Published: January 5, 2012 \\ URL: http://dx.doi.org/10.5430/ijfr.v3n1p57
}

Received: June 29, 2011

doi:10.5430/ijfr.v3n1p57

\begin{abstract}
The main purpose of this study is to examine the validity of the static trade-off theory and the pecking order theory using a French panel data. Our empirical tests provide that we can not formally reject either of the two theories explaining financing behavior. However, they confirm the importance of considerations provided by the static trade-off theory. On the contrary, when we combine the adjustment model and the pecking order model we find that the statistical power of the hierarchical model is improved and the choice of financing of French firms confirms the greatest explanatory power of the pecking order hypotheses.
\end{abstract}

Keywords: Capital Structure, Trade-Off Theory, Pecking Order Theory

\section{Introduction}

Although the capital structure policy is not a new area of research, it remains one of the most interesting and puzzling topics. The theories and explanations that have emerged have resulted in an enormous body of theoretical and empirical studies. However, no consensus has been reached yet.

The financial literature in this field was marked by the contributions of Modigliani and Miller (1958), Miller (1977) and Myers (1984). The contributions of these authors relate, primarily, to the recognition of two theses: the first relates to the absence of impact of the leverage on the market value of the firm. The second one concerns the well celebrated article of Modigliani and Miller (1958) which constitutes the starting point of the majority of the studies relating to the leverage. These two pioneers' works, by adopting a certain number of hypotheses, primarily the existence of perfect and frictionless capital markets, prove the irrelevance theorem. According to the irrelevance theorem the firm's financing policy should not affect the firm's value or its cost of capital. The firm's value is solely determined by its investment decisions. This obviously implies that there are no interactions between corporate finance and investment decisions.

This thesis was the subject of several criticisms, which is primarily due to the existence of a perfect market. The fact that the researchers neglected the imperfections of the market, in particular, the effect of the taxation; costs of bankruptcy; the costs of agency and the costs of signaling, was regarded as a limitation with this contribution. By introducing market imperfections, two research orientations appeared. The first axis, supported by Kraus and Litzenberg (1973), Scott (1976), Myers (1977) takes into account the imperfections of the market such as the taxation and the costs of bankruptcy and suggests that firms seem to get an optimal, value-maximizing debt-equity ratio by trading off the advantages of debt against the disadvantages.

The second axis takes into account the imperfections of the market such as the agency problems and asymmetries of information (Myers, 1984; Myers and Majluf, 1984). It considers the choice of the structure of the capital as a solution to the inefficiencies which characterize the decisions of investment of the firm related to the asymmetric information between managers and investors. Managers know more about the true value of the firm and the firm's riskiness while outsider investors are less informed. To avoid the underinvestment problem, managers will seek to finance the new project using a security that is not undervalued by the market, such as internal funds or riskless debt. Therefore, this affects the choice between internal and external financing. Thus, to mitigate information asymmetry, firms follow a financing hierarchy: internal funds are preferred to external financing and if the latter becomes necessary, safe debt is 
preferred to risky debt and equity issues are the lowest end choice.

Hence, research in the capital structure field is dominated by two theories: the static-trade-off theory and the pecking order theory. The main purpose of this study is to examine the empirical validity of these two theories, for a sample of French firms over the period from 1998 to 2002.

The rest of the paper is organized as follows. In the next section the theoretical background and hypotheses are presented. In sections 3 and 4, we test the static trade-off theory and the pecking order theory against the irrelevance theorem of (Modigliani and Miller (1958)). The study uses the models proposed by Shyam-Sunder and Myers (1999). It employs the partial adjustment model and a regressing model of the change in total debt level on the internal funds deficit. Furthermore, to consider the specificity of the French context (the short-term debt is not negligible) we have to supplement this approach by introducing short-term vision in financial deficit. In section 5, to reconcile the STT and the POT, we test the pecking order model and trade-off model in the same regression. Finally, the conclusions are presented in section 6 .

\section{Theories and Related Literature}

\subsection{Static Trade-Off}

In their second seminal paper, Modigliani and Miller (1963) have revised the underlying argument of their classical proposition of capital structure. They incorporate the corporate income tax and claim that the value of the firm, if levered, equals the value of the firm if unlevered plus the value of the generated tax benefit. Modigliani and Miller (1963) as well as Modigliani and Miller (1958) ignore the agency and bankruptcy costs of debt. To a certain extent, the presence of agency and bankruptcy costs of debt may outweigh its tax benefit, suggesting the existence of an optimal target financial debt ratio, under which the firm's value is maximized (Kraus and Litzenberg (1973), Scott (1976), Myers (1977)). The static trade-off theory (STT) implies that firms have a target debt ratio and try to move towards this target. According to Myers (2001), the optimal point can be attained when the marginal value of the benefits associated with debt issues exactly offsets the increase in the present value of the costs associated with issuing more debt. The benefits include the tax shield whereas the costs include expected financial distress costs (Note 1).

The static trade-off predicts that:

- Firms that possess intangible assets or high growth opportunities (high bankruptcy costs) tend to be less indebted than those with mostly tangible assets (bankruptcy costs relatively low).

- The risky firms tend to less involved in debt, anything being equal in addition.

- The debt ratio target should be different for different industries.

- The mature firms, which usually have many tangible assets, are more indebted than firms whose main business growth is largely based on research and development of technology and advertising.

- The most profitable firms are most indebted.

- The existence of a negative relationship between earnings variability and firm leverage.

- Firms with high marginal rate of imposition (most profitable and whose variation of earnings is low) are highly indebted.

- By controlling profitability, the firms with tax benefits unrelated with high debt have small debt ratios.

\subsection{The Pecking Order Theory}

The pecking order theory (POT) developed by Myers (1984) is an alternative capital structure theory. It predicts that, due to the asymmetric information and transactions costs, firms adopt a hierarchical order of financing preferences so that internal financing is preferred to external financing. If external financing is needed, firms first seek debt funding. Equity is only issued as a last resort. This ranking was motivated with reference to the Myers and Majluf (1984) adverse selection problem that arises because managers are more knowledgeable than outsiders (investors). Myers and Majluf (1984) claim that if the firm finances its new project by issuing new securities, these securities will be under-priced. This is because managers cannot credibly convey the quality of their existing assets and available investment opportunities to potential investors. As a result, outsiders may not be able to discriminate between good and bad projects, and consequently interpreting the firm's decision to issue new securities as a sign of possible bad news and then pricing new securities accordingly.

The Pecking Order Theory stipulates that:

- Firms prefer internal financing over external financing. However, if in presence of profitable investment opportunities, they choose external financing. 
- They adapt their payout ratio of dividends to their investment opportunities. The policy is rigid in order to have a sufficient cash flow which enables it to finance its investment opportunities.

- A rigid dividend policy and unpredictable fluctuations in profitability and investment opportunities of the firm suggest that internal cash flows could be higher or lower than investments. If they are lower, the firm primarily uses its liquidity or its portfolio of securities. If they are higher, the firm repays its debt or invests in liquid assets or marketable securities. If the surplus continues, it may gradually increase its payout ratio target.

- If external funding is necessary, the firm issues less risky funding: first, the debt, then hybrid securities such as convertible bonds and in the last, it issues new shares. Pecking Order theory does not predict a ratio of debt (a mix of debt and equity) well defined target because there are two types of capital: internal and external. One is at the top of the hierarchy and the other is at the bottom of the hierarchy. The debt ratio represents the accumulated firm's external financing needs.

\subsection{Empirical Evidence}

Although many previous studies have examined the pecking order theory and the static tradeoff theory, there is no consensus on the superiority of one of the theories.

In their recent study, Dufour and Molay (2010) analyzes the capital structure of 1535 French SME observed during a period of 8 years. Two representations of financing behavior are tested: the first one considers that companies implement a debt policy to reach a target debt ratio while the second one relying on a pecking order of financing considers that there is no such a target ratio. Statistical tests validate the first approach. The choice of financing of French SMEs confirms the greatest explanatory power of the target ratio method. It should be noticed that the industrial sector of the firms does not affect these results.

In similar a study, Molay (2005) tests two alternative theories of capital structure: the pecking order theory and the static trade-off theory. The empirical tests conducted on a sample of French firms listed on the Paris stock ex-change show that their financing choice seems to be more in line with the pecking order theory than with the static trade-off theory. The tested firms prefer internal financing to external financing and, when using external financing, debt is preferred to equity.

In a more recent study conducted in the context of Central and Eastern European countries, Delcoure (2007) finds a positive relationship between firms leverage ratios on the one hand, and asset tangibility, non-debt tax shield, and taxes on the other hand. In addition, a negative relationship between leverage ratios and profitability is found. Furthermore, puzzling findings related to the relationship between firm size and earnings volatility with the leverage ratios are found, as the significant signs change across countries and among the different dependent variables. Finally, Delcoure (2007) concludes that the pecking order hypothesis, the trade-off theory, and the agency theory explain the capital structure puzzle only partially in his sample countries.

Syham - Sunder and Myers (1999) test the pecking order theory and trade-off theory in the US market. For pecking order theory, they regress the firm's net debt issues on its net financing deficit. They find that the estimated coefficient of the deficit variable is close to one. Syham - Sunder and Myers (1999) interpret this result as an evidence supporting pecking order theory because a shortfall in funds is first met by debt. Furthermore, they find that the power of trade-off theory in explaining new debts issues is better than pecking order theory because when the pecking order model and trade-off model are nested in the same regression, all cases of pecking order model are rejected (they use the net financing deficit as an additional explanatory variable in their trade-off theory model).

\section{Static Trade-Off Theory: Empirical Evidence}

To test the static trade-off theory (STT) against the irrelevance theorem (Modigliani and Miller (1958)), we rely firstly on the approach initiated by Shyam-Sunder and Myers (1999), and secondly by adding a few tests to account for possible effects (sector, size, risk and capital intensity) on the behavior debt of the French firm.

The description of data, the presentation of the variables studied and the hypotheses tested are successively assessed in this section which concludes with a presentation and interpretation of the corresponding results.

\subsection{Data and Methodology}

Our sample consists of 122 French firms belonging to different sectors (Agroalimentary, chemicals, pharmaceuticals and cosmetics, basic industry, general industry and services). Given the different approaches of funding policy between financial firms and non-financial ones, it seemed appropriate to eliminate the financial firm. The choice of sectors and enterprises has been constrained by data availability.

The data used in the following study are mainly accounting data on balance sheets, income statements and cash flow. 
They are provided by the financial markets authority (AMF). The study period extends from 1998 to 2002 which amounts to 610 observations.

To test the static trade-off theory for the selected sample of French firms, models (M1) (M2) (M3) (M4) are then estimated for data consisting of 121 firms multiplied by 5 observations. To this end, we first calculated the change in long-term debt for each firm and each year. Next, we determined the variation in the ratio of long-term debt. Finally, the long-term debt target was calculated by two ways: with the approach set by Shyam-Sunder and Myers (1999) and on the basis of a debt target sector average.

\subsubsection{Dependent Variables}

The explanatory variables are classified into two groups depending on whether one wants to test the model (M1) or model (M2). Indeed the model (M1) uses the change in the amount of long-term debt us variable while the model (M2) refers to the change of the ratio of long term debt.

The variation of the long term debt is defined as follows:

$$
\Delta D_{\text {it }}=D_{\text {it }}-D_{\text {it }-1}
$$

Where $D_{i t}$ : the long-term debt of the $i^{\text {th }}$ firm at time $t$ as it appears in the balance of the $i^{\text {th }}$ firm. For each firm considered, hawse considers 5 annual observations. In total for the 122 firms in the sample used, we have 610 observations of the change of the long-term debt.

The variation in the ratio of long term debt is calculated as follows:

Where:

$$
\Delta d_{i t}=\frac{D_{i t}}{A_{i t}}-\frac{D_{i t-1}}{A_{i t-1}}
$$

$D_{\text {it }}$ : the long term debt of $i^{\text {th }}$ firm at time $t$

$A_{\text {it: }}$ the book value of assets of $i^{\text {th }}$ firm at time $t$. It is equal to the difference between total assets and net current liabilities (Shyam-Sunder and Myers (1999)).

\subsubsection{Independent Variable}

For describing the explanatory variable of the models (M1) and (M2), it is necessary to determine, as a preliminary, the long-term debt targets as defined by Shyam-Sunder and Myers $\left(\mathrm{D}^{*}{ }_{\mathrm{it}}\right.$ : the target ratio of the $\mathrm{i}^{\text {th }}$ firm) and by us as a sectorial average $\left(D^{*}{ }_{j t}\right.$ : the ratio targets of the $\mathrm{j}^{\text {th }}$ sector $)$.

$$
D_{i t}^{*}=\frac{\sum_{t=1998}^{2002} \frac{D_{i t}}{A_{i t}}}{T} C A P I_{I T}
$$

Where:

T: the period of the study. It corresponds to five years $(\mathrm{T}=5)$.

CAPI ${ }_{\mathrm{it}}$ : the book value of the credit of the $\mathrm{i}^{\text {th }}$ firm at the period $\mathrm{T}$

Thereafter, we calculated the explanatory variables $z_{i t}$ and $z^{\prime}{ }_{i t}\left(w_{i t}\right.$ and $\left.w_{j t}\right)$ : the distance between the target value and the delayed value (the target ratio and the ratio delayed) for one year of the long-term debt; determined by the following expression:

$$
\begin{array}{ll}
\mathrm{z}_{\mathrm{it}}=\mathrm{D}_{\mathrm{it}}^{*}-\mathrm{D}_{\mathrm{it}-1} & w_{i t}=d^{*}{ }_{i t}-\frac{D_{i t-1}}{A_{i t-1}} \\
\mathrm{z}_{\mathrm{it}}^{\prime}=\mathrm{D}^{*}{ }_{\mathrm{jt}}-\mathrm{D}_{\mathrm{it}-1} & w_{i t}^{\prime}=d^{*}{ }_{j t}-\frac{D_{j t-1}}{A_{i t-1}}
\end{array}
$$

Where:

$$
\begin{aligned}
& \mathrm{d}^{*}{ }_{\mathrm{it}} \text { : the debt ratio targets of } \mathrm{i}^{\text {th }} \text { firm } \\
& \mathrm{d}^{*}{ }_{\mathrm{jt}} \text { : the debt ratio targets of } j^{\text {th }} \text { sector }
\end{aligned}
$$

\subsubsection{Regression Model and Hypotheses}

The static trade-off theory rests on the assumption according to which the managers are in search of an optimal structure of the capital. Random events can move them away from this objective. Nevertheless, the managers must converge 
there gradually. If the optimal debt ratio is stable, it is then possible to note a behavior of return to the average (Mean reverting behavior). A simple form of the model of adjustment explains the variations of the debt ratio by the deviations of the current ratio from the target ratio.

The first stage of our research consists in checking this result. For that, we carried out the following regressions:

$$
\begin{aligned}
& \Delta D_{i t}=a+b_{T A}\left(D^{*}{ }_{i t}-D_{i t-1}\right)+e_{i t} \\
& \Delta d_{i t}=a+b_{T A}\left(d^{*}{ }^{*}-\frac{D_{i t-1}}{A_{t-1}}\right)+e_{i t} \\
& \Delta D_{i t}=a+b_{T A}\left(D^{*}{ }_{j t}-D_{i t-1}\right)+e_{i t} \\
& \Delta d_{i t}=a+b_{T A}\left(d^{*}{ }_{j t}-\frac{D_{i t-1}}{A_{i t-1}}\right)+e_{i t}
\end{aligned}
$$

The hypotheses to be tested are written as follows:

$$
\left\{\begin{array}{l}
H_{0}: b_{T A}=0 \\
H_{1}: b_{T A} \neq 0
\end{array}\right.
$$

For each firm and each year, variables $\Delta D_{i t}\left(D^{*}{ }_{i t}-D_{i t-1}\right)$ and $\left(D^{*}{ }_{j t}-D_{i t-1}\right)$ were reported at book value of assets of each firm only as a precaution against heteroscedasticity (Shyam-Sunder and Myers (1999)). Furthermore, our analysis is limited to the carrying value of debt and the debt ratio is expressed only at book value.

In order to highlight the possible effects of size (Note 2), risk (Note 3) and capital intensity (Note 4) on the long-term debt from the French firms in the sample, we adopted an approach which consists of classifying firms into two categories around the median of each variable: SMEs and large firms, less risky and risky, capital-intensive and low capital intensive and then estimate the Model (M1) (M2) (M3) (M4).

The model estimation is performed through the software "SPSS".

\subsection{Regression Results}

The first step of our research is to estimate the models (M1) and (M2). Estimation of the model (M1) shows the following results ( Table 1).

$$
\Delta D_{i t}=301729-0.414\left(D^{*}{ }_{i t}-D_{i t-1}\right)
$$

(M1) (Note 5)

$$
(3.591)^{*} \quad(-12.162)^{* *} \text { (Note 6) }
$$

Analysis of the results of the estimation of model (M1) shows that the coefficient associated with the variable $\left(\mathrm{D}^{*}{ }_{i t}-\right.$ $\left.\mathrm{D}_{\mathrm{it}-1}\right)$ is not affected by the expected sign $(-0.414<0)$. Nevertheless, it verifies the assumption that its value is less than the unit $(-0.414<1)$. In addition, to the $5 \%$ level, the variable $\left(\mathrm{D}^{*}\right.$ it $\left.-\mathrm{D}_{\mathrm{it}-1}\right)$ is contributory to the explanation of debt financing in the long term.

At 5\% level, the intercept is significant. The coefficient of determination of the model (M1) is equal to 0.27 . Moreover, the results of the estimation of model (M2) that the variable is measured by the variation long-term debt are as follows:

$$
\Delta d_{i t}=0.028+0.853\left(d^{*}{ }^{*}{ }_{i t}-d_{i t-1}\right)
$$

$$
(14.930)^{* *}
$$

The estimation of model (M2) shows that the use of debt as measured by the variation of long-term debt is significantly related to the distance between the target ratio and the ratio of delayed debt long term. This result is consistent with expectations of the STT.

In addition, the intercept is not significant. The coefficient of determination of the model (M2) is 0.359 . The results of estimation of models (M1) and (M2) are reported in Table (1). 
The results of regression concerning model (M1) of the aggregate basis show that at the $5 \%$ level, the long-term debt of firms in the sample moves away significantly from the target level of the long-term debt $\left(b_{\mathrm{TA}}=-0.414<1\right.$ and Student $t$ -12.162). Contrary to the predictions of the adjustment model of capital structure, the coefficient associated with the variable $(\mathrm{D} *$ it - Dit- 1$)$ is negative and significant at $5 \%$ level.

This finding invalidates the hypothesis that change in long-term debt partially absorbs the difference between the target and the lagged value of long-term debt.

Moreover, the speed of adjustment towards the target value of long-term debt is low. Indeed, an adjustment factor of $-41.4 \%$ reflects the relatively rapid adjustments in respect to long term debt. In addition, the coefficient of the variable $z_{\text {it }}$ is significantly less than unity, suggesting the existence of positive adjustment costs.

The estimation of model (M2) shows results consistent with the expectations. In fact, the coefficient of the distance between the target ratio and the ratio of delayed long-term debt is positive and significant at $5 \%\left(\mathrm{~b}_{\mathrm{TA}}=0.853\right.$ and t-statistic $=14,930)$. An adjustment factor of $85.3 \%$ reflects a relatively high speed of adjustment and shows that the variation in the ratio of long-term debt absorbs quickly the distance between the target ratio and the ratio of delayed long-term debt.

\subsubsection{Regression Results of Firms According to the Restraint Characteristic}

The estimation results of models (M1) and (M2) are presented in Table 2.

The estimation of the model (M2) for small firms show that at the $5 \%$ level, small firms converge significantly and partially to the target level of long-term debt $\left(\mathrm{b}_{\mathrm{TA}}=0.760\right.$ and Student's $\left.\mathrm{t}=7.442\right)$. In addition, the adjustment factor is less than unity suggesting the existence of positive adjustment costs associated with market imperfections. A speed adjustment of $76 \%$ demonstrates that the change in long-term debt absorbs quickly the distance between the target and the lagged value of long-term debt for small firms. Estimation of the model (M1) for small firms leads to similar results to those obtained in the analysis of model (M2).

The results of the estimation of model (M2) for large firms shows that the ratio of long-term debt of large firms in the sample converges quickly and significantly to the target ratio $\left(b_{\mathrm{TA}}=0.939\right.$ and student's $\left.\mathrm{t}=16.654\right)$.

Estimation of the model (M1) for the least risky companies shows that at the 5\% level, the long-term debt of firms in the sample moves away significantly from the target level of long-term debt. This finding invalidates the hypothesis that the change in long-term debt partially absorbs the difference between the target and the lagged value of long-term debt. Moreover, regression results of the model (M2) show that the ratio of long-term debt converges significantly and quickly to the target ratio $\left(b_{\mathrm{TA}}=0.987\right.$ and Student's $\left.\mathrm{t}=15.758\right)$.

The results of the estimation of model (M1) for risky firms show that at the 5\% level, the long-term debt of French firms is significantly closer to the target $\left(b_{\mathrm{TA}}=0.690\right.$ and Student's $\left.\mathrm{t}=11.986\right)$. This result confirms the hypothesis that changes in long-term debt partially absorbs the difference between the target and the lagged value of long-term debt. The estimation of model (M2) shows results very close to those observed in the analysis model (M1).

Estimation of the model (M1) for lowly capital intensity firms highlight a negative and significant adjustment factor at the $5 \%$ level $\left(\mathrm{b}_{\mathrm{TA}}=-0.644\right.$ and Student's $\left.\mathrm{t}=-19.292\right)$. Thus, the debt ratio moves away partially from the target value.

The results of the estimation of the model (M2) for highly capital intensive firms are consistent with the predictions of the model of capital structure adjustment. It should be noticed that the adjustment coefficient is positive and significant $\left(\mathrm{b}_{\mathrm{TA}}=0.931\right.$ and Student's $\left.\mathrm{t}=10.029\right)$. In addition, the adjustment factor is less than unity, suggesting the existence of positive adjustment costs. Estimation of the model (M1) shows results very close to those observed during the analysis of the model (M2).

To sum up, the test of the STT against the irrelevance theorem for our sample of French firms shows that:

> Firms tend to converge to an optimal overall capital.

$>$ The existence of a sectoral effect is validated. By choosing an optimal structure by sector, the change in long-term debt absorbs, with a specific speed to each sector, the difference between the target and the lagged value of long-term debt.

$>$ The existence of positive adjustment costs. The French firms of the sample do not completely and probably converge at any time to the target level of long-term debt. Nevertheless, the costs of deviations from an optimal structure are generally not high enough to prevent French firms from the sample used to make more use of long-term debt.

$>$ The existence of a size effect: large firms in our sample seem to converge more quickly towards the target level of long-term debt. 
The existence of risk effect: the less risky firms seem to converge more quickly towards the target level of long-term debt.

$>$ The most capital intensive firms seem to converge more quickly towards the target level of long-term debt.

\section{Pecking Order Theory: Empirical Evidence}

This part aims to test the Pecking Order Theory which can explain the financial behavior of French firms in the sample against the irrelevance theorem (Modigliani and Miller, 1958). First, we selected the approach initiated by Shyam-Sunder and Myers (1999) and extend this approach to be compatible with the French view (the short-term debt is not negligible). The description of data, presentation of the variables studied and the identification of hypotheses tested are successively presented in this part which ends with a summary and interpretation of results.

\subsection{Data and Methodology}

To test the POT we used the same sample, the same study period and the same data sources as in the empirical study conducted in the second section. Thus, the study was conducted on 122 French firms from different sectors over the period from 1998 to 2002.

An examination of the POT for the sample of French firms selected requires measuring the funds flow deficit in each period and for each firm. Data are collected from balance sheets and financial statements. To this end, we determined the variables needed to calculate the funds flow deficit of firms. Moreover, the explanatory variables as defined by Shyam-Sunder and Myers (1999) were calculated.

\subsubsection{Dependent Variables}

It should be stressed that our study is based on the same explanatory variables used in the empirical analysis in the second section of the present work.

The variation of the long-term debt is defined as follows:

$$
\Delta \mathrm{D}_{\text {it }}=\mathrm{D}_{\mathrm{it}} \quad-\mathrm{D}_{\mathrm{it}-1}
$$

Where: $D_{i t}$ : the long-term debt of ${ }^{t}$ firm at time $t$ as it appears in its balance sheet

For each firm considered, hawse considers 5 annual observations. In total and for the 122 firms in the sample used, we have 610 observations of the variation of the long-term debt.

The variation in the ratio of long-term debt is calculated as follows:

$$
\Delta d_{i t}=\frac{D_{i t}}{A_{i t}}-\frac{D_{i t-1}}{A_{i t-1}}
$$

Where:

$D_{\text {it }}$ : the long-term debt of $i^{\text {th }}$ firm at time $t$.

$\mathrm{A}_{\mathrm{it}}$ : the net book of assets of $\mathrm{i}^{\text {th }}$ firm at time $\mathrm{t}$. It is equal to the difference between total assets and net current liabilities (Shyam-Sunder and Myers, (1999)).

\subsubsection{Independent Variable}

For the purposes of this study, we assume that a firm faces in each period to fund requirements. The funds flow deficit of the firm in year $t$ is given by:

$$
\begin{aligned}
\mathrm{DEF}_{\mathrm{t}}= & \mathrm{DIV}_{\mathrm{t}}+\mathrm{X}_{\mathrm{t}}+\Delta \mathrm{W}_{\mathrm{t}}+\mathrm{Rt}-\mathrm{C}_{\mathrm{t}} \\
\operatorname{def}{ }^{\prime}{ }_{t}= & \frac{D E F t}{A_{t}} \\
\mathrm{DEF}_{\mathrm{t}} & =\mathrm{DIV}_{\mathrm{t}}+\mathrm{X}_{\mathrm{t}}+\Delta \mathrm{W}_{\mathrm{t}}+\Delta \mathrm{Ch}_{\mathrm{t}}+\Delta \mathrm{DCT}_{\mathrm{t}}+\mathrm{R}_{\mathrm{t}}-\mathrm{C}_{\mathrm{t}} \\
\operatorname{def}^{\prime}{ }_{t} & =\frac{D E F_{t}^{\prime}}{A_{t}}
\end{aligned}
$$

Where:

$$
\begin{aligned}
& \mathrm{C}_{\mathrm{t}}=\text { operating cash flows after interest and taxes. } \\
& \text { Div }_{\mathrm{t}}=\text { dividend payments. }
\end{aligned}
$$


$\mathrm{X}_{\mathrm{t}}=$ capital expenditure.

$\Delta \mathrm{W}_{\mathrm{t}}=$ net increase in working capital.

$\mathrm{R}_{\mathrm{t}}=$ current portion of long-term debt at start of period.

$\mathrm{CH}_{\mathrm{t}}=$ liquidity and short term investments.

$\mathrm{DCT}_{\mathrm{t}}=$ the short-term debt.

$\mathrm{D}_{\mathrm{t}}=$ the long-term debt.

$A_{t}=$ net book assets (Note 7)

$\mathrm{d}_{\mathrm{t}}=\mathrm{D}_{\mathrm{t}} / \mathrm{A}_{\mathrm{t}}$ : the book debt ratio.

4.1.3 The Estimation Technique and Testable Hypotheses

In its simplest form, the POT states that when internal cash flows of the firm do not adjust its investment opportunities and real commitments on distribution of dividends, it emits then the debt without risk. It never proceeds with the issuance of new shares except where it can only issue junk bonds and when the bankruptcy costs are high. Based in part on the approach of Shyam - Sunder and Myers (1999), the funds flow deficit of the firms are assumed to be met by the change of the ratio of long-term debt and the change in long-term debt, and secondly we have reformulated the funds flow deficit so that it can account for the short term vision. The purpose of this study is to verify this result. For this model (M5) (M6) (M7) and (M8) are then estimated.

$$
\begin{aligned}
& \Delta D_{i t}=a+b_{P O} D E F_{i t}+e_{i t} \\
& \Delta d_{i t}=a+b_{P O} d e f_{i t}+e_{i t} \\
& \Delta D T O T_{i t}=a+b_{P O} D E F^{\prime}+e_{i t} \\
& \Delta d T O T_{i t}=a+b_{P O} d e f^{\prime}{ }_{i t}+e_{i t}
\end{aligned}
$$

Where:

$\Delta \mathrm{D}_{\text {it }}$ : the long-term debt issued by $\mathrm{i}^{\text {th }}$ firm (or repaid if surplus).

$D E F_{i}$ the financial deficit of the $i^{\text {th }}$ firm.

$\operatorname{def}_{\mathrm{it}}$ the financial deficit of $\mathrm{i}^{\text {th }}$ firm divided by its total equity.

$\Delta \mathrm{d}_{\mathrm{it}}$ : the change in the ratio of long-term debt.

$\triangle \mathrm{DTOT}_{\mathrm{it}}$ : net total debt issued (or repaid if surplus) by the firm $\mathrm{i}$.

$D E F^{\prime}$ : fixed needs of $i^{\text {th }}$ firm.

$\Delta \mathrm{dTOT}_{\mathrm{it}}$ : the change in the ratio of total net debt.

$\mathrm{def}{ }_{i t}$ : the corrected financial funds flow deficit of the $\mathrm{i}^{\text {th }}$ firm divided by equity.

The test of significance of the coefficient $b_{\mathrm{PO}}$ is written as follows (Note 8):

$$
\left\{\begin{array}{l}
H_{0}: b_{P O}=0 \\
H_{1}: b_{P O} \neq 0
\end{array}\right.
$$

In order to test the POT, the two hypotheses stating that $\mathrm{a}=0$ and $\mathrm{b}_{\mathrm{po}}=1$ are verified. The model estimation is tested by software "SPSS".

\subsection{Rgression Results}

Analysis of the results of estimating models (M5) shows that the coefficient ( $\left.\mathrm{b}_{\mathrm{PO}}\right)$ is different from unity and statistically significant at $5 \%$ level. This result suggests that at the $5 \%$ level the variable DEF has a significant contribution to explaining the change of long-term debt. Moreover, with a correlation coefficient which equals zero results of the estimation of model (M6) are not taken into account.

The results of the estimation model (M7) did not differ from those obtained when estimating the model (M5). Indeed, the coefficient associated with the variable deficit is different from unity and statistically significant at $5 \%$ level. Thus, the indicator of deficit plays a role in explaining the variation in total net debt. In addition, the intercept is different of zero and significant at $5 \%$ level. In contrast, when the observed variable is the debt ratio and not the change of debt, the results do not support the POT. 


\subsubsection{Regression Results by Sector}

The results of estimating models (M5) (M6) (M7) and (M8) are presented in Table (4).

The results of the estimation of the model (M5) show that at 5\% level the variable deficit is significantly contributory to explaining the variation in long-term debt for the Agro alimentary sector. The results of the estimation of model (M6) did not differ from those obtained when estimating the model (M5).

For the chemicals sector, pharmaceuticals and cosmetics, the indicator deficit plays a role in explaining the variation in long-term debt (total net debt) in the model (M5), (M6), (M7) and (8).

The regression results of models (M7) and (M8) for basic industry sector and general industry sector are consistent with predictions of the POT. Indeed, the deficit variable contributes significantly to explaining the change in net total debt and net total debt ratio.

For the service sector, the regression results of the model (M5) show that the indicator of the deficit plays a role in explaining variation in long-term debt.

\subsubsection{Regression Results According to the Feature Selected}

The results of the regression models (M5) and (M6) show that the DEF variable could explain the change of the long-term debt (rate of long-term debt) for the large firms, the least risky firms and the low capital intensive firms. In addition, regression results of the models (M7) and (M8) are not different from those obtained during the estimate of the models (M5) and (M6).

Ultimately, the test of the theory POT against the irrelevance theorem for the sample of the French firms retained leads to the following results:

$>$ The financial deficit contributes only partially to the explanation of the change of the long-term debt for our total sample. Consequently, the hypothesis of POT can be accepted.

$>$ The existence of a sectoral effect for the short term vision. Indeed, the change of the long-term debt is explained significantly by the deficit for the sectors agroalimentary, chemistry, pharmacy, cosmetic and service whereas the change of the clear total debt is explained significantly by the deficit corrected for the basic industry and general industry sectors.

$>$ The existence of a size, risk and capital high intensity effects. Indeed, the indicator of financial deficit plays a significant role in the explanation of the variation of the long-term debt for the large firms, the least risky firms and the low capital intensive firms.

$>$ Clearly, our empirical results do not make it possible to conclude on a better explanation of the behaviors by a model or another. From where follows the idea, already suggested by Syham-Sunder and Myers (1999) to combine the two approaches to try to explain the variety of the behaviors.

\section{Combining Trade-Off and Pecking Order Models}

Previous studies have shown that understanding the behavior of firms in terms of the choice of financing passes certainly through conciliation and not confrontation of the two analytical well known frameworks.

In the following, we propose to analyze models combining each of the factors that might explain the financial behavior of French firms in the sample by the static trade-off theory or the pecking order theory. We would then know whether the explanatory power and significance of the coefficients of the models (M1), (M2), (M3), (M4), (M5) and (M6) will be improved taking into account both specific factors to the STT and to POT.

\subsection{Regression Model}

In order to verify the improvement in explanatory power and significance of the coefficients of the models (M1), (M2), (M3), (M4), (M5) and (M6), we tested the following regressions.

$$
\begin{aligned}
& \Delta D_{i t}=a+b_{T A}\left(D^{*}{ }_{i t}-D_{i t-1}\right)+b_{P O} D E F_{i t}+e_{i t} \\
& d_{i t}=a+b_{T A}\left(d^{*}{ }_{i t}-\frac{D_{i t-1}}{A_{i t-1}}\right)+b_{P O} d e f_{i t}+e_{i t} \\
& \Delta D_{i t}=a+b_{T A}\left(D^{*}{ }_{i j}-D_{i t-1}\right)+b_{P O} D E F_{i t}+e_{i t} \\
& d_{i t}=a+b_{T A}\left(d^{*}{ }_{i j}-\frac{D_{i t-1}}{A_{i t-1}}\right)+b_{P O} d e f_{i t}+e_{i t}
\end{aligned}
$$




\subsection{Regression Results of the Model Combining Partial Adjustment and the Hierarchy of Financing Models}

The results of the models estimation (M9) and (M10) show that their coefficients of determination have increased considerably, which means that the addition of the indicator of the distance between the target and the lagged value of long term debt improves the explanatory power of models (M5) and (M6).

The combination of the two models of capital structure has improved the significance of the coefficient associated with the variable DEF.

\subsubsection{Regression Results by Sector}

The estimate of the models (M11) and (M12) have led to results similar to those obtained during the estimate of the models (M9) and (M10).

Ultimately, the combination of the partial adjustment model and the hierarchy of financing model improve considerably the statistical capacity of the hierarchical model and confirm the assumptions of the POT in the majority of the sectors selected.

How we can explain that the combination of two approaches, predicting different behaviors, makes it possible better to account for the reality of the practices that each model separately?

One can imagine two explanations:

- The managers have a target ratio but they show opportunism, in the way they take to reach it. Nevertheless, this way is directed by the hierarchical financing.

- There are two non reconcilable types of behavior, but which cohabit in our sample, and probably in the population. Taking into account these two models makes it possible to increase the variance explained without the need of justifying the real combination of the practices in the same firm.

\section{Discussion and Conclusion}

This paper presents the empirical tests of data from a sample of French firms and which are intended to explain their behavior in terms of financing.

In the second section, we empirically tested the static trade-off theory against the irrelevance theorem for a sample of 122 French firms from different sectors over a period from 1998-2002. To this end we adopted the approach of Shyam-Sunder and Myers (1999). Our studies highlight the following results:

$>$ A convergence to a global optimal structure of capital from firms in the sample.

The existence of a sectoral effect is validated. By choosing an optimal structure sector, the change in long-term debt absorbs with a speed specific to each sector, the difference between the target and the lagged value of long-term debt.

$>$ The existence of positive adjustment costs made by firms in the sample probably did not converge completely at any time to the target level of long-term debt. Nevertheless, the costs of deviations from an optimal structure are generally not high enough to prevent French firms from the sample used to make more use of long-term debt.

$>$ The existence of size effect: large firms in the chosen sample seem to converge more quickly towards the target level of long-term debt (which is consistent with the assumptions of STT).

$>$ The existence of risk effect: the less risky firms seem to converge more quickly towards the target level of long-term debt.

$>$ The most capital-intensive firms seem to converge more quickly towards the target level of long-term debt (STT predicts that investment is positively related to debt).

The third section presents an empirical study of the behavior dictated by the POT. We empirically tested the relationship between the change in long-term debt and financial deficit, firstly, as defined by Shyam-Sunder and Myers (1999) and then by introducing the specific French context which do not neglect the short-term debts, and a new financial deficit is calculated.

Empirical tests of the theory of the POT against the irrelevance theorem show that:

$>$ The financial deficit contributes only partially to the explanation of the change in long-term debt for the full sample of French firms. Therefore, the hypotheses of the POT are accepted.

$>$ The existence of a sectoral effect for short-term vision: the change in long-term debt is significantly explained by the deficit for the agro alimentary, chemicals, pharmaceuticals, cosmetics and service sectors while the 
change in total net debt is significantly explained by the deficit adjusted for industry sectors basic and general industry.

$>$ The existence of a size, risk and capital intensity effect. Indeed, the indicator of financial deficit plays a significant role in explaining the variation in long-term debt for large firms, less risky and low capital intensive firms.

This paper concludes with an empirical study combining the model of the Trade-Off and the hierarchy of financing. The inclusion of two schemes of analysis greatly improves the statistical power of the hierarchical model and confirms the hypotheses of the POT in the majority of the selected sectors.

To sum up, this study shows that we can not formally reject either of the two theories explaining financing choices. However, it confirms the importance of considerations provided by the static trade-off theory.

However, if this study helps to better understand financial behavior of French firms in the sample, it does not include less serious restrictions. Indeed:

The partial adjustment model that we applied to determine the convergence behavior of French firms in the sample supposes the stability of the target level of long-term debt. However, the determinants of debt such as the variability of profits, tangibility, growth opportunities, size, profitability, tax savings which are not linked to debt are likely to vary over time for the same firm. This captures the dynamic nature of capital structure. We should therefore use a debt target which changes in the time.

Moreover, the factor used in the adjustment model is assumed to be constant over time and identical for all firms. Nevertheless, the speed of adjustment towards optimal capital structure depends on several factors specific to each firm such that the distance between the target and the lagged value of long-term debt, the firm size, growth opportunities, profitability, general economic conditions, etc. Thus, the adjustment is done at a rate specific to each firm (Heshmati (2001)).

In addition, the hierarchical model we used does not necessarily evaluate the pecking order theory. According to Chirinko and Singha (2000), the hierarchical model initiated by Shyam-Sunder and Myers (1999) is likely to be rejected even when the firm's behavior is consistent with the assumptions of the POT. The hierarchical model can be also used even when the financial behavior firms is inconsistent with the POT.

However, the results demonstrated for the sample of French firms open several avenues for future research. Indeed, alternative tests are necessary to enable beneficiaries to identify the determinants of capital structure and also enable to distinguish between rival hypotheses.

Finally, a better understanding of the relationship between the financing of the firm measured by stock (the levels of debt and equity in relation to the target level) and the financing of the firm measured in flow (which title to be emitted at a given moment) can reconcile the different theories of capital structure (Barclay and Smith (1999)).

\section{References}

Daskalakis, N. \& Psillaki, M. (2009). Are the determinants of capital structure country or firm specific? Small Business Economics. Vol. 33 N. 3. p. 319-333. http://dx.doi.org/10.1007/s11187-008-9103-4.

Delcoure, N. (2007). The determinants of capital structure in transitional economies. International Review of Economics \& Finance 16. 400-415. http://dx.doi.org/10.1016/j.iref.2005.03.005.

D'Mello, R. \& Farhat, J. (2008). A comparative analysis of proxies for an optimal leverage ratio. Review of Financial Economics. vol. 17 n3. p. 213-227. http://dx.doi.org/10.1016/j.rfe.2007.06.001.

Dominique, D. \& Molay, E. (2010). La Structure Financière Des PME Françaises : Une Analyse Sectorielle Sur Données De Panel. Crises et nouvelles problématiques de la Valeur. Nice: France.

Frank, M. Z. \& Goyal, V. K. (2003). Testing the Pecking Order Theory of Capital Structure. Journal of Financial Economics. vol. 67. p. 217-248. http://dx.doi.org/10.1016/S0304-405X(02)00252-0.

Harris, M. et Raviv, A. (1991). The Theory of Capital Structure. Journal of Finance. vol. 46 n1. p.297-355. http://dx.doi.org/10.2307/2328697

Helwege, J. \& Liang, N. (1996). Is there a pecking order? Evidence from a panel of IPO firms. Journal of Financial Economics. vol. 40 n3. p. 429-458. http://dx.doi.org/10.1016/0304-405X(95)00851-5 .

Jalilvand, A. \& Harris, R. S. (1984). Corporate Behaviour in Adjusting to Capital Structure \& Dividend Targets: An 
Econometric Study. Journal of Finance. vol. 39. p. 127-145. http://dx.doi.org/10.2307/2327672

Jensen, M. (1986). Agency Costs of Free Cash-Flow. Corporate Finance \& Takeovers. American Economic Review. vol. 76. p. 323-339.

Miller, M. H. (1988). The Modigliani-Miller Propositions. After Thirty Years. Journal of Economic Perspectives. vol. 2 n4. Fall 1988. p. 99-120.

Modigliani, F. \& Miller, M. H. (1958). The Cost of Capital. Corporation Finance \& the Theory of Investment. American Economic Review. vol. 48. p. 261-297.

Modigliani, F. \& Miller, M. H. (1963). Corporate Income Taxes \& the Cost of Capital: A Correction. American Economic Review. vol. 53 n3. p. 433-443.

Molay, E. (2005). La structure financière du capital : tests empiriques sur le marché français. Finance Contrôle Stratégie. vol. 8 n4. p. 153-175.

Myers, S. C. et Majluf, S. (1984). Corporate Financing \& Investment Decisions When Firms Have Information That Investors do not Have. Journal of Financial Economics. vol. 13 n2. p. 187-221. http://dx.doi.org/10.1016/0304-405X(84)90023-0

Myers, S. C. (1984). The Capital Structure Puzzle. Journal of Finance. July. vol. 39 n3. p. 575-592.

Myers, S. C. (2001). Capital Structure. Journal of Economic Perspectives. vol. 15 n2. Spring. p. 81-102.

Shyam-Sunder, L. et Myers, S. C. (1999). Testing Static Trade-Off against Pecking Order Models of Capital Structure. Journal of Financial Economics. vol. 51. p. 219-244. http://dx.doi.org/10.1016/S0304-405X(98)00051-8

\section{Notes}

Note 1. Myers (1984) focuses on the tradeoff between tax benefits and bankruptcy costs when describing the static tradeoff theory. Several other papers incorporate more factors into the static tradeoff theory, like agency costs (see, e.g., De Miguel and Pindado, 2001; Flannery and Rangan, 2006).

Note 2. The approximate variable used is the average of the capital engaged for each firm

Note 3.The approximate variable used is the standard deviation of the capacity of self-financing divided by the average of this last.

Note 4. The approximate variable used is the average of ratio investment by capital engaged for each firm

Note 5. Values in parentheses indicate the statistical " $t$ " of student

Note $6 .{ }^{* *}$ Indicates that the coefficient is significant at $5 \%$ level.

Note 7. $A_{t}$ equals net total book assets less current liabilities.

Note 8 . This test is done through the Student t statistic

Table 1. Regression results of model estimates (M1) and (M2)

\begin{tabular}{|l|l|l|}
\hline & $\mathrm{M} 1\left(\Delta \mathrm{D}_{\text {it }}\right)$ & $\mathrm{M} 2\left(\Delta \mathrm{d}_{\text {it }}\right)$ \\
\hline Regression constant & 301729 & 0.028 \\
& $(2.634)^{*}$ & $(1.429)$ \\
\hline Independent variable & -0.414 & 0.853 \\
\hline $\mathrm{R}^{2}$ & 0.270 & 0.359 \\
\hline Number of observation & 605 & 605 \\
\hline
\end{tabular}


Table 2. Regression results of models (M1) and (M2) for French firms in the sample according to each characteristic restraint

\begin{tabular}{|c|c|c|}
\hline Small Business & $\mathrm{M} 1\left(\Delta \mathrm{D}_{\mathrm{it}}\right)$ & $\mathrm{M} 2\left(\Delta \mathrm{d}_{\mathrm{it}}\right)$ \\
\hline Regression constant & $\begin{array}{l}2547 \\
(2.061)^{*}\end{array}$ & $\begin{array}{l}0.58 \\
(1.621)\end{array}$ \\
\hline Independent variable & $\begin{array}{l}0.501 \\
(10.319)^{* *}\end{array}$ & $\begin{array}{l}0.760 \\
(7.442)^{* *}\end{array}$ \\
\hline $\mathrm{R}^{2}$ & 0.358 & 0.226 \\
\hline \multicolumn{3}{|l|}{ Large Firms } \\
\hline Regression constant & $\begin{array}{l}580697 \\
(3.595)^{*}\end{array}$ & $\begin{array}{l}0.002 \\
(0.104)\end{array}$ \\
\hline Independent variable & $\begin{array}{l}-0.414 \\
(-8.823)^{* *}\end{array}$ & $\begin{array}{l}0.939 \\
(16.654)^{* *}\end{array}$ \\
\hline $\mathrm{R}^{2}$ & 0.276 & 0.576 \\
\hline \multicolumn{3}{|l|}{ Less risky firms } \\
\hline Regression constant & $\begin{array}{l}480284 \\
(3.187)^{*}\end{array}$ & $\begin{array}{l}0.00 \\
(-0.020)\end{array}$ \\
\hline Independent variable & $\begin{array}{l}-0.465 \\
(-10.521)^{* *}\end{array}$ & $\begin{array}{l}0.987 \\
(15.758)^{* *}\end{array}$ \\
\hline $\mathrm{R}^{2}$ & 0.359 & 0.558 \\
\hline \multicolumn{3}{|l|}{ Risky firms } \\
\hline Regression constant & $\begin{array}{l}20552 \\
(0.475)\end{array}$ & $\begin{array}{l}0.059 \\
(1.634)\end{array}$ \\
\hline Independent variable & $\begin{array}{l}0.690 \\
(11.986)^{* *}\end{array}$ & $\begin{array}{l}0.819 \\
(9.886)^{* *}\end{array}$ \\
\hline $\mathrm{R}^{2}$ & 0.418 & 0.328 \\
\hline \multicolumn{3}{|l|}{ Low capital intensive firm } \\
\hline Regression constant & $\begin{array}{l}250634 \\
(2.374)^{*}\end{array}$ & $\begin{array}{l}0.032 \\
(1.498)\end{array}$ \\
\hline Independent variable & $\begin{array}{l}-0.644 \\
(-19.292)^{* *}\end{array}$ & $\begin{array}{l}0.762 \\
(12.228)^{* *}\end{array}$ \\
\hline $\mathrm{R}^{2}$ & 0.662 & 0.443 \\
\hline \multicolumn{3}{|l|}{ High capital intensive firm } \\
\hline Regression constant & $\begin{array}{l}137415 \\
(1.782) \\
\end{array}$ & $\begin{array}{l}0.022 \\
(0.648) \\
\end{array}$ \\
\hline Independent variable & $\begin{array}{l}0.442 \\
(9.088)^{* *}\end{array}$ & $\begin{array}{l}0.931 \\
(10.029)^{* *}\end{array}$ \\
\hline $\mathrm{R}^{2}$ & 0.287 & 0.328 \\
\hline
\end{tabular}


Table 3. Regression results of model (M5) (M6), (M7) and (M8)

\begin{tabular}{|l|l|l|l|l|}
\hline & $(\mathrm{M} 5)$ & $(\mathrm{M} 6)$ & $(\mathrm{M} 7)$ & $(\mathrm{M} 8)$ \\
\hline & 44615 & 0.042 & 283802 & 0.062 \\
Regression constant & $(0.619)$ & $(1.709)$ & $(2.037)^{*}$ & $(0.894)$ \\
\hline & 0.680 & -0.000002 & -0.175 & -0.003 \\
Independent variable & $(19.253)^{* *}$ & $(-0.167)$ & $(-4.010)^{* *}$ & $(-0.607)$ \\
\hline $\mathrm{R}^{2}$ & 0.482 & 0.000 & 0.039 & 0.001 \\
\hline
\end{tabular}

Table 4. Regression results models (M5) (M6) (M7) and (M8) for French firms by sector.

\begin{tabular}{|l|l|l|l|l|}
\hline Agroalimentary sector & $(\mathrm{M} 5)$ & $(\mathrm{M} 6)$ & $(\mathrm{M} 7)$ & $(\mathrm{M} 8)$ \\
\hline \multirow{2}{*}{ Regression Constant } & 1426 & 0.019 & -463292 & -0.148 \\
& $(0.017)$ & $(0.303)$ & $(-1.269)$ & $(-0.407)$ \\
\hline \multirow{2}{*}{ Independent variable } & 0.692 & 0.127 & 1.02 & -1.061 \\
\hline $\mathrm{R}^{2}$ & $(6.805)^{* *}$ & $(1.70)$ & $(2.324)$ & $(-5.621)^{*}$ \\
\hline Chemical and pharmaceutical sector & 0.556 & 0.072 & 0.127 & 0.461 \\
\hline & & & & \\
\hline Regression Constant & 51627 & -0.023 & -134321 & 0.005 \\
\hline Independent variable & $(0.856)$ & $(-0.711)$ & $(-0.887)$ & $(0.103)$ \\
\hline $\mathrm{R}^{2}$ & 0.564 & 0.362 & -0.383 & -0.217 \\
\hline Basic Industrial sector & $(10.394)^{* *}$ & $(3.685)^{*}$ & $(-5.764)^{* *}$ & $(-2.046)^{*}$ \\
\hline & 0.675 & 0.207 & 0.390 & 0.074 \\
\hline Regression Constant & & & & \\
\hline & 243687 & 0.038 & 222056 & 0.033 \\
Independent variable & $(3.348)^{*}$ & $(1.404)$ & $(1.389)$ & $(0.195)$ \\
\hline $\mathrm{R}^{2}$ & 0.135 & 0.084 & -0.334 & -0.002 \\
\hline General industrial sector & $(2.248)^{*}$ & $(1.265)$ & $(-4.607)^{* *}$ & $(-0.368)$ \\
\hline & 0.062 & 0.02 & 0.216 & 0.002 \\
\hline Regression Constant & & & & \\
\hline Independent variable & 226445 & 0.002 & 254689 & -0.063 \\
& $(2.219)^{*}$ & $(0.048)$ & $(2.696)^{* *}$ & $(-0.871)$ \\
\hline $\mathrm{R}^{2}$ & 0.199 & 0.333 & -0.268 & 0.664 \\
\hline Service sector & $(1.782)$ & $(3.761)^{*}$ & $(-4.578)^{* *}$ & $(8.583)$ \\
\hline & 0.025 & 0.104 & 0.147 & 0.377 \\
\hline & & & & \\
\hline & $(11.982)^{* *}$ & $(2.735)^{*}$ & $(-1.725)$ & $(3.145)$ \\
\hline & 0.589 & 0.07 & 0.028 & 0.089 \\
\hline
\end{tabular}


Table 5. Regression results of the models (M5) (M6) (M7) and (M8) for French firms according the feature selected.

\begin{tabular}{|c|c|c|c|c|}
\hline Agroalimentary sector & (M5) & (M6) & (M7) & $(\mathrm{M} 8)$ \\
\hline Regression Constant & $\begin{array}{l}1426 \\
(0.017)\end{array}$ & $\begin{array}{l}0.019 \\
(0.303)\end{array}$ & $\begin{array}{l}-463292 \\
(-1.269)\end{array}$ & $\begin{array}{l}-0.148 \\
(-0.407)\end{array}$ \\
\hline Independent variable & $\begin{array}{l}0.692 \\
(6.805)^{* *}\end{array}$ & $\begin{array}{l}0.127 \\
(1.70)\end{array}$ & $\begin{array}{l}1.02 \\
(2.324)\end{array}$ & $\begin{array}{l}-1.061 \\
(-5.621)^{*}\end{array}$ \\
\hline $\mathrm{R}^{2}$ & 0.556 & 0.072 & 0.127 & 0.461 \\
\hline \multicolumn{5}{|c|}{ Chemical and pharmaceutical sector } \\
\hline Regression Constant & $\begin{array}{l}51627 \\
(0.856)\end{array}$ & $\begin{array}{l}-0.023 \\
(-0.711)\end{array}$ & $\begin{array}{l}-134321 \\
(-0.887)\end{array}$ & $\begin{array}{l}0.005 \\
(0.103)\end{array}$ \\
\hline Independent variable & $\begin{array}{l}0.564 \\
(10.394)^{* *}\end{array}$ & $\begin{array}{l}0.362 \\
(3.685)^{*}\end{array}$ & $\begin{array}{l}-0.383 \\
(-5.764)^{* *}\end{array}$ & $\begin{array}{l}-0.217 \\
(-2.046)^{*}\end{array}$ \\
\hline $\mathrm{R}^{2}$ & 0.675 & 0.207 & 0.390 & 0.074 \\
\hline \multicolumn{5}{|l|}{ Basic Industrial sector } \\
\hline Regression Constant & $\begin{array}{l}243687 \\
(3.348)^{*}\end{array}$ & $\begin{array}{l}0.038 \\
(1.404) \\
\end{array}$ & $\begin{array}{l}222056 \\
(1.389) \\
\end{array}$ & $\begin{array}{l}0.033 \\
(0.195) \\
\end{array}$ \\
\hline Independent variable & $\begin{array}{l}0.135 \\
(2.248)^{*}\end{array}$ & $\begin{array}{l}0.084 \\
(1.265)\end{array}$ & $\begin{array}{l}-0.334 \\
(-4.607) * *\end{array}$ & $\begin{array}{l}-0.002 \\
(-0.368)\end{array}$ \\
\hline $\mathrm{R}^{2}$ & 0.062 & 0.02 & 0.216 & 0.002 \\
\hline \multicolumn{5}{|l|}{ General industrial sector } \\
\hline Regression Constant & $\begin{array}{l}226445 \\
(2.219)^{*}\end{array}$ & $\begin{array}{l}0.002 \\
(0.048) \\
\end{array}$ & $\begin{array}{l}254689 \\
(2.696)^{* *}\end{array}$ & $\begin{array}{l}-0.063 \\
(-0.871) \\
\end{array}$ \\
\hline Independent variable & $\begin{array}{l}0.199 \\
(1.782)\end{array}$ & $\begin{array}{l}0.333 \\
(3.761)^{*}\end{array}$ & $\begin{array}{l}-0.268 \\
(-4.578)^{* *}\end{array}$ & $\begin{array}{l}0.664 \\
(8.583)\end{array}$ \\
\hline $\mathrm{R}^{2}$ & 0.025 & 0.104 & 0.147 & 0.377 \\
\hline \multicolumn{5}{|l|}{ Service sector } \\
\hline Regression Constant & $\begin{array}{l}-248312 \\
(-1.035)\end{array}$ & $\begin{array}{l}-0.078 \\
(-0.949)\end{array}$ & $\begin{array}{l}782252 \\
(1.620)\end{array}$ & $\begin{array}{l}-0.018 \\
(-0.085)\end{array}$ \\
\hline Independent variable & $\begin{array}{l}0.789 \\
(11.982)^{* *}\end{array}$ & $\begin{array}{l}0.369 \\
(2.735)^{*}\end{array}$ & $\begin{array}{l}-0.153 \\
(-1.725)\end{array}$ & $\begin{array}{l}0.869 \\
(3.145)\end{array}$ \\
\hline $\mathrm{R}^{2}$ & 0.589 & 0.07 & 0.028 & 0.089 \\
\hline
\end{tabular}

Table 6. Regression results of the models (M9) (M10)

\begin{tabular}{|l|l|l|}
\hline Global Basis & (M9) & (M10) \\
\hline \multirow{2}{*}{ Regression constant } & 86006 & 0.024 \\
$(1.3)$ & $(0.233)$ \\
\hline$\left(D^{*}{ }_{i t}-D_{i t-1}\right)$ & -0.249 & 0.833 \\
$\left(d^{*}{ }_{i t}-d_{i t-1}\right)$ & $(-8.831)^{* *}$ & $(15.063)^{* *}$ \\
\hline $\begin{array}{l}D E F_{i t} \\
d e f_{i t}\end{array}$ & 0.571 & 0.000002 \\
$\mathrm{R}^{2}$ & $(16.489)^{* *}$ & $(-0.175)$ \\
\hline
\end{tabular}


Table 7. Regression results of the models estimation (M11) and (M12) for French firms in the sample.

\begin{tabular}{|c|c|c|}
\hline Agroalimentary sector & (M11) & (M12) \\
\hline Regression Constant & $\begin{array}{l}-61388 \\
(-0.848)\end{array}$ & $\begin{array}{l}0.014 \\
(0.225)\end{array}$ \\
\hline $\begin{array}{l}\left(D_{i j}^{*}-D_{i t-1}\right) \\
\left(d^{*}{ }_{i j}-d_{i t-1}\right)\end{array}$ & $\begin{array}{l}0.431 \\
(3.757)^{*}\end{array}$ & $\begin{array}{l}0.205 \\
(2.071)^{*}\end{array}$ \\
\hline $\begin{array}{l}D E F_{i t} \\
d e f_{i t}\end{array}$ & $\begin{array}{l}0.441 \\
(3.995)^{* *}\end{array}$ & $\begin{array}{l}0.153 \\
(2.103)^{*}\end{array}$ \\
\hline $\mathrm{R}^{2}$ & 0.681 & 0.171 \\
\hline \multicolumn{3}{|c|}{ Chemical and pharmaceutical sector } \\
\hline Regression Constant & $\begin{array}{l}59964 \\
(1.019) \\
\end{array}$ & $\begin{array}{l}-0.022 \\
(-0.799)\end{array}$ \\
\hline $\begin{array}{l}\left(D^{*}{ }_{i j}-D_{i t-1}\right) \\
\left(d^{*}{ }_{i j}-d_{i t-1}\right)\end{array}$ & $\begin{array}{l}0.133 \\
(1.872)\end{array}$ & $\begin{array}{l}0.084 \\
(1.649)\end{array}$ \\
\hline $\begin{array}{l}D E F_{i t} \\
d e f_{i t}\end{array}$ & $\begin{array}{l}0.511 \\
(8.475)^{* *}\end{array}$ & $\begin{array}{l}0.396 \\
(4.862)^{* *}\end{array}$ \\
\hline $\mathrm{R}^{2}$ & 0.696 & 0.468 \\
\hline \multicolumn{3}{|l|}{ Basic Industrial sector } \\
\hline Regression Constant & $\begin{array}{l}203078 \\
(2.716)^{*}\end{array}$ & $\begin{array}{l}0.025 \\
(0.940)\end{array}$ \\
\hline $\begin{array}{l}\left(D^{*}{ }_{i j}-D_{i t-1}\right) \\
\left(d^{*}{ }_{i j}-d_{i t-1}\right) \\
\end{array}$ & $\begin{array}{l}0.091 \\
(1.886)\end{array}$ & $\begin{array}{l}0.213 \\
(2.815)^{*}\end{array}$ \\
\hline $\begin{array}{l}D E F_{i t} \\
d e f_{i t}\end{array}$ & $\begin{array}{l}0.217 \\
(2.958)^{*}\end{array}$ & $\begin{array}{l}0.105 \\
(1.639)\end{array}$ \\
\hline $\mathrm{R}^{2}$ & 0.104 & 0.113 \\
\hline \multicolumn{3}{|l|}{ General industrial sector } \\
\hline Regression Constant & $\begin{array}{l}253182 \\
(2.520)^{*}\end{array}$ & $\begin{array}{l}-0.028 \\
(-0.748)^{* *}\end{array}$ \\
\hline $\begin{array}{l}\left(D^{*}{ }_{i j}-D_{i t-1}\right) \\
\left(d^{*}{ }_{i j}-d_{i t-1}\right)\end{array}$ & $\begin{array}{l}-0.151 \\
(-2.826)^{*}\end{array}$ & $\begin{array}{l}0.397 \\
(6.023)^{* *}\end{array}$ \\
\hline $\begin{array}{l}D E F_{i t} \\
d e f_{i t}\end{array}$ & $\begin{array}{l}0.213 \\
(1.958)\end{array}$ & $\begin{array}{l}0.328 \\
(3.525)^{*}\end{array}$ \\
\hline $\mathrm{R}^{2}$ & 0.086 & 0.252 \\
\hline \multicolumn{3}{|l|}{ Service sector } \\
\hline Regression Constant & $\begin{array}{l}-249671 \\
(-1.037) \\
\end{array}$ & $\begin{array}{l}-0.171 \\
(-2.317)\end{array}$ \\
\hline $\begin{array}{l}\left(D^{*}{ }_{i j}-D_{i t-1}\right) \\
\left(d^{*}{ }_{i j}-d_{i t-1}\right)\end{array}$ & $\begin{array}{l}0.076 \\
(0.613)\end{array}$ & $\begin{array}{l}0.554 \\
(5.679)^{* *}\end{array}$ \\
\hline $\begin{array}{l}D E F_{i t} \\
d e f_{i t}\end{array}$ & $\begin{array}{l}0.814 \\
(10.470)^{* *}\end{array}$ & $\begin{array}{l}0.560 \\
(4.577)^{*}\end{array}$ \\
\hline $\mathrm{R}^{2}$ & 0.591 & 0.298 \\
\hline
\end{tabular}

